\title{
Meeting the Need for a Technologically Driven Justice Delivery System: The Elixir of Rights and Judicial Expediency
}

\author{
Foluke Dada1, Emily Alemika ${ }^{2 *}$ \\ ${ }^{1}$ Ekiti State University, Ado Ekiti, Nigeria \\ ${ }^{2}$ Nigerian Institute of Advanced Legal Studies, Supreme Court Complex, Abuja, Nigeria \\ Email: folukedada@gmail.com, *ealemika@yahoo.com
}

How to cite this paper: Dada, F., \& Alemika, E. (2020). Meeting the Need for a Technologically Driven Justice Delivery System: The Elixir of Rights and Judicial Expediency. Beijing Law Review, 11, 805-825. https://doi.org/10.4236/blr.2020.113049

Received: June 14, 2020

Accepted: September 26, 2020

Published: September 29, 2020

Copyright $\odot 2020$ by author(s) and Scientific Research Publishing Inc. This work is licensed under the Creative Commons Attribution International License (CC BY 4.0).

http://creativecommons.org/licenses/by/4.0/

\section{(c) (i) Open Access}

\begin{abstract}
The quality of justice is found in its efficacy while the promptness of justice determines its effect. Hence, the aphorism, "justice delayed is justice denied". It is well known fact that the justice system in Nigeria, like many developing countries, is like igniting a snail on a hundred-kilometer journey. The problem of delay in justice is compounded in an unforeseen period like the world's current state of the Coronavirus pandemic. By virtue of the national lock-down, the justice system has been on a halt and as such, every aspect of life which is tied to a virile judicial system is also affected. The aim of this paper therefore, is an attempt to analyse how technology can be employed for an effective justice delivery system while the pandemic situation persists. This exercise begins with an examination of the legal provisions available in Nigerian law to meet the demands for a technological-driven effective justice system. This is done by analysing the various provisions of the Evidence Act, High Courts Civil Procedure Rules, Administration of Criminal Justice Laws of States, Courts' Practice Directions and other relevant provisions. Hence, the thrust of this paper is to elicit palpable elixirs aimed to achieve the decongestion of courts and improve access both during emergencies such as the COVID-19 situation and in the normal course of justice delivery thereafter.
\end{abstract}

\section{Keywords}

Technology, Administration of Justice, Corona Virus, Pandemic, Lockdown, Courts, Human Rights

\section{Introduction}

Owing to the outbreak of the Coronavirus known as COVID-19 pandemic glo- 
bally in December, 2019, there has been a global lock-down on all aspects of life including the administration of justice. The administration of justice has been put on hold for a period of time in order to minimise the risk of person to person transmission. On $23^{\text {rd }}$ March 2020, it became clear that the COVID-19 virus had gained momentum in Nigeria, leading to a total lock-down of both government functionaries and private sectors of the nation. This prompted the Chief Justice of Nigeria to issue Circular (Circ.No.NJC/CIR/HOC/11631) to short down the judicial system all over the nation in order to safeguard the health of Judges, litigants and their counsels. Thus, by this Circular, all Heads of Courts in the Federal and State Judiciaries were directed to suspend courts activities on the further notice, except for urgent or time-bound matters. This is based upon the principle of necessity of life, and as such, the law recognises the principle that de morte hominis nulla est cunctation longa. This is a legal maxim which means-when the delay of human being is concerned, no delay is long. Imminently, the effect of this is that there is an emergency in the justice system, an emergency that requires urgent action and innovation both in the substantive and procedural aspects of the Law of our dear nation.

Traditionally, courtroom is the only scene for trial of cases in Nigeria except in cases of visit to locus in quo as enabled by the provisions of the Evidence Act (S.127 (2) (a), 2011) which allows court to adjourn to visit the locus in quo while the proceeding may continue at the scene of the inspection. It has become obvious that this traditional system cannot stand the test of time, particularly in the era of COVID-19. The limitations of a system whereby the physical attendance of parties, counsel and witnesses are required in a courtroom exposed to hazards at a time such as this when the major cities and their courtrooms are under lockdown to the detriment of urgent matters of paramount to public importance. This could cause grave and irreparable damage to private parties. Hence, there is the need to search for alternatives.

It is important to note that a total lock-down of the justice system in Nigeria at this time definitely has nebulous effects on the other sectors of life considering the fact that Nigerian courts are faced with a backlog of cases. It is however desirable to ensure that justice is not further delayed during this period of emergency as delay in justice is the defeat of the very essence of justice. The dilemma facing the judicial sector at this point in time is that by following the traditional court proceedings system the lives of litigants, court officials and judges are greatly exposed to health risks, if the courts continue to sit in the usual way. Yet, the lockdown of courts has the capability of adversely affecting all areas of lives including the enjoyment of the non-derogable fundamental human rights which have been described as sacrosanct in the case of (Anthony Olubunmi Okogie v. Attorney-general of Lagos State (1981). The lock-down also affects both commercial transactions, governance and all sectors of the society. This unfortunate development points to the fact that only the use of technology through virtual court hearings, can be effective to ensure that the justice system is not totally short down in Nigeria. 
Consequently, the Chief Justice of the Nation in a circular (Ref. No. NJC/CIR/HOC/II/660 2020) transmitted the National Judicial Council Guidelines for Court virtual Sittings and Related Matters in the COVID-19 Period to all heads of courts. In line with the guidelines, some states have also promulgated Practice Directions for the COVID-19 period to ensure that while justice is not grounded to a halt, the pandemic is not also allowed to keep spreading in our courtrooms. The National Judicial Council guidelines provide for a system which employs technology and the observance of social distancing in the filing of cases, courtroom virtual sittings, payment of filing fees and service of court processes. It is against this background that this paper examines the innovations of these Practice Directions as promulgated during the COVID-19 period and their relevance to the progress of our justice system during the pandemic period and subsequently.

\section{COVID-19 Practice Directions and Provisions of Law in Nigeria}

By virtue of Section 274 of the1999 Constitution of the Federal Republic of Nigeria (CFRN) (as amended in 2011), the Chief Judge of a High Court has the power to make rules regulating the practice and procedure of courts. This procedure is made in form of the Practice Directions which are made for different kinds of cases. The purpose is to ensure proper administration of justice in totality. These Practice Directions have the force of law and are in fact binding (Nwakwo v. Yar'adua (2010). In the case of Buhari v. INEC (2008), the Court further held that Practice Direction is the last authority in the area of conflict in the hierarchy of our jurisprudence. Thus, Practice Directions have always been employed to assist the court in peculiar cases and as the needs arise; Hence, the new Practice Directions are apt and timely during this period of emergency as a result of the pandemic COVID-19 Virus.

Following the directives of the National Judicial Commission (NJC) and the steps taken by the Chief Justice of Nigeria (CJN) to institute general Practice Directions, the Chief Judge of the High Court of the Federal Capital Territory also releases its new Practice Directions (COVID-19 Practice Direction (2020)), with effective from $11^{\text {th }}$ of May, 2020 to, "regulate the sitting of the Courts of the Federal Capital Territory, Abuja to ensure the effective conduct of court business without compromising the health and safety of Court staff, counsel, litigants, and other court users".

The FCT Practice Direction on its own is a hybrid system which adopts both the conventional court sittings and the use of technology, while matters are still heard in open courts, litigants and counsels must maintain social distancing. For instance, by paragraph 8 of the Practice Direction, all criminal proceedings requiring the presence of defendants have been suspended till further notice. However, bail applications, remand proceedings and overnight cases are to be entertained, provided that "the court shall exercise necessary caution" to ensure that suspects are not remanded in correctional centers. Some other states of the 
Federation have since follow suit to develop their respective Practice Directions for virtual court hearings for prevention of the spread of the pandemic in courtrooms. For the purposes of highlights and for comparative analysis, this paper shall focus on two states of the Federation (Lagos and Anambra States), that have evolved new Practice Directions and putting them into uses.

\subsection{Practice Direction for Remote Hearing of Cases in the Lagos and Anambra State Judiciaries 2020: A Critical View}

The Chief Judge of Lagos State, pursuant to the provisions of the law (S. 6(6) CFRN 1999 and other statutes), made the Practice Direction for "Remote Hearing of Cases in the Lagos State Judiciary". The learned Chief Judge stated that the said Direction was made in furtherance of Section 6(6) of the Constitution of the Federal Republic of Nigeria (CFRN), Section 87 of the High Court Law of Lagos State 2015, Order 49 Rules 1, 2 and 3 of the High Court of Lagos State (Civil Procedure) Rules 2019, Lagos State Magistrates' Court (Civil Procedure) Rules 2009, Administration of Criminal Justice Law of Lagos State 2015. The various laws and rules as identified above all point to the same or similar purposes of empowering the Chief Judges of the High Courts across the nation to make Practice Directions for the operation of certain matters before the courts whenever the needs arise. For instance, the Constitution provides, "Subject to the provisions of any law made by the House of Assembly of a State, the Chief Judge of a State may make rules for regulating the practice and procedure of the High Court of the State (S. 274, CFRN, 1999).

On the other hand, His Lordship, the Chief Judge of Anambra Stat (Justice O. M. Anyachebelu (2020)), also deploys its own Practice Directions in response to COVID-19 (Practice Direction No.2, Anambra (2020), but with a different twist to the system of operation. While the Lagos Practice Directions is more technology-driven, the Anambra system is designed to set precautions against the spread of the virus. For further critical review, it might be important to conduct a comparative analysis into the provisions of both Practice Directions for practical exercises.

In Lagos Practice, the Direction makes it clear that its major preoccupation is to ensure access to justice and expeditious hearing of cases without allowing the spread of the deadly COVID-19 virus to halt the administration of justice. This is in pari-materia with Para. 5(a) of the Anambra State Practice Direction which provides that "attention shall be focused on bail applications, remand proceedings, interlocutory motions, Fundamental Rights applications, final addresses, rulings/judgments, and any other cause or matter considered urgent or time-bound". The Lagos direction on the other hand, makes it clear from its tenor that the most efficient way of ensuring that litigants are not denied access to justice during this emergency situation is the adoption of remote hearing (Paras. $1 \& 2$ Practice Direction-Lagos 2020). However, the Anambra Practice Direction (PRACTICE DIRECTION) does not look in the direction of technology, it rather chooses to apply the conventional court sitting but with provisions on the 
reduction of physical contact and decongestion of the courtroom. For instance Para.5 (a) of the Direction provides that the Honourable Judges and Learned Magistrates/Presidents of Customary Courts shall ensure that the rules of physical distancing and the wearing of face masks by counsel, litigants and court staff are strictly observed and enforced in the court premises and courtrooms.

Fundamentally, while the Practice Directions differs in operation or application, the principles remain the same or similar-that is to prevent COVID-19 from spreading while court hearings are in session.

\subsection{The Aim and Objectives of the Lagos State Practice Directions}

The main purpose of new Practice Directions (Practice Direction) of Lagos State is for the acceleration of criminal justice system in the face of COVID-19; while minimising the rate of the transmission of the pandemic virus among the Justices, Judges, the other courts staff, the litigants and their Counsels and the general public who might have interests in the cases being tried in the courts of law in Nigeria. Therefore, considering the nature and features of the old or traditional court practices which include:

1) Filing of cases;

2) Service of Court Process;

3) Pre-Trial Conference or Case Management Conference (see generally Order 27, High Court of the Federal Capital Territory, Abuja Civil Procedure Rules 2018; Order 27 High Court of Lagos State Civil Procedure Rules 2019);

4) Trial and taking of evidence;

5) Final Address (adoption of final written addresses) and;

6) Delivery of Judgment and/or Ruling.

The Lagos PRACTICE DIRECTION came up with these main objectives which include:

1) timely and efficient disposal of cases;

2) use of suitable technology;

3) just determination of the proceedings; and

4) efficient use of available judicial and administrative resources (Para.4 Practice Direction Lagos State Judiciary 2020).

Hence, the main aim of the Lagos (Practice Direction) is to provide not only for timely, effective and efficient justice deliveries with the aids of technological devices; especially, in this pandemic period; but in so doing, the courts staff are well protected from the deadly diseases. Thus, the Practice Direction provides a deviation from the traditional way of conducting all the affairs of the various courts using the concept of technology for quick dispensation of cases without the need to have litigants and their counsels physically present in courtrooms.

Typically, in a traditional form of court practices and proceedings, a suit is said to have commenced when a party presents all the requisite documents before the registrar and pays all the filing fees on the action (Stanley-Idum \& Agaba, 2015). This then involves a series of activities which include the signing and endorsement of the writs or originating process, assessment of the documents, 
payment of the filing fees as assessed. Traditionally, all of these activities required direct contact with persons where documents might have been infested with the virus. However, the new Practice Direction has replaced the physical contact with the use of electronic mails or Whatsapp platform (Para.7 Practice Direction Lagos State Judiciary, 2020). In the same vein, assessment of processes, documents as well as the payment of filing fees are also being conducted or done through text messages which are now fully online processes.

\subsection{Prospects and Challenges of Operating Virtual Courts' Hearings with the Aids of the New Practice Direction in Nigeria}

Arrays of prospects as regard virtual courts' hearings are as displayed in the various analyses above. Among the chief prospects is the dispensation of justice in the court of law without having recourse to physical appearance and or contact. For example, the traditional court practices and proceedings which entail writs of summon, signing and endorsement of documents, assessments, payment of filing fees, personal service of summons, and lots more; all require contacts, which in this pandemic period are not expedient. The new Practice Direction has now taken over these activities with the aid of electronic devices, thus, reducing the chances of the transmission of the deadly diseases through court physical settings.

With the new Practice Directions, it is expected that the new mode would come with its own challenges, even with recorded prospects. For instance, the contentious part of the Lagos Practice Direction is the service of processes. Paragraphs 11 and 12 of the Practice Direction state that, "processes can now be served electronically via WhatsApp or electronic mail", notwithstanding the provision of Order 9 of the Civil Procedure Rules relating to service of Court processes. Order 9, Rule 2 requires personal service on the party to be served. Thus, what would ordinarily be known under the law as substituted service is now taken to be personal service.

In legal parlance, substituted service is originally meant to be employed only after personal service is impossible. Also, the said provision will impliedly be made to override the provision of Order 9 Rule 14 which relates to the fact that there is a time-limit during the day that a court process may be served (which is typically between the hour of six in the morning to six o'clock in the evening), since electronic media has to be employed in the service of processes, it will then mean that service would be effected anytime of the day. This may constitute a challenge with the problem of internet-network failure, with electricity epileptic service in Nigeria. In furtherance of this provision, the direction inputs a relic of the principle regarding sending letters and documents as laid down in the age-long Adams v. Lindsell (1818) case law which affirmed that the service of a court process shall be complete upon sending and time shall be computed to start running from the date that the said message was sent (Part 13 of Lagos Practice Direction). 
The potential danger in this provision is in the fact that Nigeria is a country where digital and internet service is yet to become an affordable service for all. In some cases, a text message may not be delivered to the recipient in three days until there is a phone call to follow-up with the message, let alone internet services that are not accessible or affordable to all. In $21^{\text {st }}$ century Nigeria, there are legal practitioners that are not computer literate, unable to acquire digital computing, epileptic supply of electricity to power mobile phones and computers and more. Thus, this provision may work hardship on litigants who are served with court processes they may not be able to access or understand!

It is imperative to draw on the point that the provision of paragraphs 11,12 and 13 of the PRACTICE DIRECTION under consideration is intended to override the provisions of the Court Civil Procedure Rules (both High Court and Magistrate). The question therefore is, whether a Practice Direction can validly override the court rules. It is noteworthy that Practice Direction is the last authority in area of conflict in the hierarchy of our jurisprudence. This Practice Direction that is occasioned by COVID-19 is no exception. This is to say that where there is a conflict between the Court Rules and a Practice Direction, the Court Rules shall prevail. It is however, submitted that even the court rules have the purpose or cardinal aim of helping the court to achieve justice in all cases and as such, where its provisions do not become effective in achieving the said justice, it will be safe for the court to jettison it and adopt the system that is capable of achieving justice.

The submission here is that the Practice Direction in this instance has not gone ultra vires. From the tenor of the Direction, it seems that this provision excluding personal service does not apply to criminal trial. This is because the provisions of the Administration of Criminal Justice Law is not excluded in the provisions of Practice Direction above, and as such, looking at copious sections of the Administration of Criminal Justice Law of Lagos of 2011, service of all processes including summons, warrants and other proofs of evidence are meant to be served personally (Section 86, 88 and 92 of Administration of Criminal Justice Law of Lagos, ACJL 2011) on the defendant except where leave has been granted for substituted service (S. 88 ACJL).

In the process of trial, the Practice Direction provides a form of voluntary rather than mandatory submission to remote hearing, this means that during the process of scheduling which is a part of case management conference, parties can voluntarily submit to remote hearing of cases (Para.15 PRACTICE DIRECTION Lagos 2020). The provision of paragraph 15 says "Parties or their Counsel may indicate voluntary participation in the Remote Hearing through the official email of the Court". By virtue of this provision, if a claimant in a time-bound case or emergency consents to remote hearing, it will still not be valid if the unscrupulous defendant who needs to "buy time" and frustrate the course of justice does not consent to remote hearing, it is therefore, submitted that the voluntariness of this provision may not help the court to achieve the desired result of disposing the time-bound and urgent cases during the COVID-19 period. 
Also, the Direction provides that the mode of conducting remote trial shall be by ZOOM or SKYPE or other video communication means approved by the court (Para. 16) This is yet the most progressive provision relating to conduct of cases in recent times in Nigeria as it is the best avenue to achieve the project of a digital courtroom, unfortunately, it doubtful as yet the most complicated provision which may later pose itself to be difficult to realise. This is due to the fact that the quality of video calls in Nigeria may not be reliable. Counsels in some of the cases that have been tried remotely in the Lagos State High Court have to first deal with the problem of network connection, most of the statements from those hearing are; "My Lord, can you see me?, my lord, can you hear me"? This is an experiment that should not even be undertaken in the process of giving evidence, this is because of the fact that the court has to observe the demeanour of every witness giving evidence, and in the nature of giving testimony, the witness is not expected to consult any book or anything to prompt him except in cases of refreshing the memory of a witness. How then do we know the demeanour of a witness whom the judge cannot see clearly owing to poor network connection? Another challenge here is that once there is a poor connection in the process of taking evidence of a witness, the court is likely to be left with no option than to adjourn the hearing. This is most likely to affect the entire process if the court has to adjourn while a witness is still in the process of examination.

To minimise the defect above, the PRACTICE DIRECTION of the High Court of the Federal Capital Territory released for the COVID-19 appears to be more realistic. It provides that Causes and Matters and other proceedings that can be determined on the basis of affidavit evidence may, as far as practicable, be heard and disposed of by Remote Hearing on virtual platforms such as Zoom, Microsoft Team, Skype or other audio or visual platforms as may be approved by the Chief Judge. This includes cases initiated by originating summons or originating motion, applications for enforcement of fundamental rights and interlocutory motions as well as adoption of written final addresses and delivery of judgments/Rulings (Para. 9 of the Practice Direction of the FCT 2020). The Abuja provision here is more realistic since the procedure will not include taking of evidence but the court simply gives its ruling after the litigants have addressed the court.

Another challenge associated with the online case hearing is the cost of conducting these video trials which is quite humongous such that indigent litigants run the risk of being excluded from this process where it is unaffordable. In Lagos State, the first matter that was heard under this procedure was the murder case of the State of Lagos v. Olalekan Hameed (2019) which was slated for judgment on the 4th of May, 2020 before the Honourable Justice Mojisola Dada of the Lagos High Court sitting in Ikeja. This case was delivered via ZOOM network with both members of the bar and the bench participating from their various chambers. The cost when computed together could be so enormous in Nigeria, considering the fact that data charges are not so affordable with attended challenges of accessing internet services. In this case, the defendant was sentenced 
to death by hanging over the killing of a 76 year old woman. This constitutes a testing ground as to whether the new Practice Direction would survive the test of time and be sustained

One issue that may be raised in the delivery of judgment through online hearing is whether it could be said that remote media would constitute presence of the accused as required by law. It will be stated for the purpose of better comprehension that it is part of the requirement of a fair trial (S.36 CFRN, 1999) which is guaranteed under the Constitution of the Federal Republic of Nigeria, 1999; that an accused person must be present all through the trial and trial in absentia is strictly prohibited by law unless he misconducts himself by disrupting the proceedings. This is in furtherance of Section 208, Administration of Criminal Justice Law of Lagos, 2011 (So also, S. 266, Administration of Criminal Justice Act, 2015; Section 210 Criminal Procedure Act (Chief of Air Staff v. Iyen (2005) ALL FWLR).

It can be argued that the provision of the Practice Direction cannot be said to violate a fair trial, this is because, the purpose of requiring the defendant to be present at the trial is to witness and know how the case is made against him. Therefore, any form of presence that will allow the defendant to be able to answer the case against either by him or through his Counsel and meaningfully participate in his trial would suffice. However, it was argued by some proponents that this does not constitute a physical presence of an accused person within the Constitutional provision (Ezeze v. The State (2005) ALL FWLR).

As has been contended, the new Practice Directions as evolved by various Courts in the country are as result of the needs to curtail the pandemic virus from ravaging human lives. Therefore, whatever is expedient to curtail the harmful impacts of the virus on human existence as well as not compromising or jeopardising the rights of both the accused and the innocent citizens is worth the efforts; while the State is in search of permanent Solutions to the pandemic attacks on human lives.

\section{Critical Issues in the Use of Technology and Admissibility of Evidence in the Administration of Criminal Justice in Nigeria}

There is a saying that goes thus; "for every disappointment there lays blessings in disguise" COVID-19 pandemic is no exception. In spite of the challenges imposed on every sphere of life globally, the Nigerian nation inclusive; some positive effects are beginning to emerge. This is evidence in the national's judiciaries whereby, in the wake of the general lockdown, the various courts all over the nation were also short down to curtail possible transmission of the deadly virus; in order to secure the safety and protections of judges, the justices and other staff of the judiciaries, as well as the litigants, their Counsels and the general public that may have needs to witness courts' proceedings. This singular action in turn had virtually paralysed the functionality of the national judiciaries which in no doubt had adversely affected not only the functional delivery of justice, the legal practi- 
tioners whose livelihood dependent on their private practices have also been seriously affected. The effort to redeem time, secure jobs and restore timely justice deliveries and yet secure maximum protections for the entire judiciaries, brought about the newly ICT based Practice Directions. It is worth noting that blessings seem to be in disguise arising from the incidental measure to curtail the spread of COVID-19 and the so-called new Practice Directions.

The Practice Direction is not so new neither is it alien to the administration of Justice, in the sense that the numerous provisions of various statutory provisions in Nigeria such as the Administration of Criminal Justice Act, 2015; the Evidence Act (as amended in 2011) and other existing courts Practice Directions had actually envisage the needs for most courts proceedings including case management to be fully automated in order to meet up with the international best practices in the national judiciaries. Therefore, what the judiciary is witnessing as regards the "New Practice Directions" is simply a "blessings in disguise" not only to reawaken the judiciaries to their enormous and onerous tasks of setting up virile automated system but, COVID-19 has come to accelerate the processes. Below are some of the array of provisions of various laws in Nigeria which serve as evidence of preparatory grounds and stepping stones for the emergence of the COVID-19 motivated "new Courts Practice Directions".

\subsection{The Practice Direction of 2020 and the Provisions of Laws Relating to Automation of Courts Practices and Proceedings}

As noted earlier, there are many of the courts' practices and proceedings which although by tradition are manual but can be automated and or digitalised. Such practices include but not limited to; originating summons and motions; services of court processes on litigants; the actual conduct of cases in the court (which involves the interfaces of Judges, legal counsels and their clients, prosecutors and witnesses); as well as recording of confessional statements of offenders, and so on. These and many others constitute courts' practices that are amenable or adaptable to digitalisation. We shall highlight some of the practices and back them up with some statutory provisions and decides cases where possible.

There are four main means of commencing actions before the High Courts in Nigeria-by; originating summons, originating motions, petition and writ of summons. Among these four models, originating summons and originating motions appear more flexible and amenable to virtual hearings. This is simply because, there are different kinds of actions that do not require taking of evidence in the court of law before such cases are heard and disposed of. Hence, most of those matters which include application of Fundamental Human Rights, Interpretation of Statutes, Deeds etc. which are not contentious in nature are instituted by originating motions/Application and originating summons, because they do not require taking of evidence except in certain situations. Therefore, what is required is for counsel to formally move a motion requesting the courts or judges that an action be heard virtually. Hence, Administration of justice may dictate that all motions and matters coming by way of originating summons be 
heard virtually. This way some courts' processes could be made more flexible whereby such cases can be heard on non-juridical days and non-juridical hours. The Non-juridical days include Saturdays, Sundays and public holidays while non-juridical hours will mean the period outside 9 forenoon to 4 afternoon.

Additionally, S. 84 of the Evidence Act (as amended in 2011) sought to accommodate the admissibility of electronic evidence by providing the legal framework where electronic documents that were hitherto inadmissible under the general law of evidence become admissible in a court proceeding. The use of technology in Nigeria and recordings of such will be subject to the provisions of Section 84 (1) of the Evidence Act which provides thus:

In any proceedings, a statement contained in a document produced by a computer shall be admissible as evidence of any fact stated in it of which direct oral evidence would be admissible if it is shown that the conditions in subsection (2) of this section are satisfied in relation to the statement and computer in question

Subsection (2) provides thus, the conditions referred to in subsection (1) of this section are:

That the document containing the statement was produced by the computer during a period over which the computer was used regularly to store or process information for the purpose of any activities regularly carried on over that period, whether for profit or not, by any body, whether corporate or not, or by individual;

That over that period there was regularly supplied to the computer in the ordinary course of those activities information of the kind contained in the statement or of the kind from which the information so contained is derived;

That throughout the material part of that period, the computer was operating properly, or if not, that in any respect in which it was not operating properly or was cut of operation during that part of that period was not such as to affect the production of the document or the accuracy of its contents; and

That the information contained in the statement reproduced or is derived from information supplied in the ordinary course of such activities.

The Supreme Court in interpreting this section held in (Dickson v. Sylva (2017) that compliance with section 84(1) and (2) is enough to render a document admissible and prove electronic record. This was similarly held in the case of (Orogun \& Anor vs. Fidelity Bank (2018).

Interestingly, S. 84 appears to cover the information supplied to the electronic device by the party supplying the same. Hence, it is safe to say that an electronic document of record can only be produced and tendered by the maker. When documents obtained from the internet e.g. via Google, Internet explorer, e-books, 
online journals, articles etc. particularly those obtained through the computer, open access websites or other electronic devices, it appears that such persons may not be able to rely on the documents since they have no ownership or knowledge as to their veracity or in fact the process of storage of such information as stated in Section 84(2) of the Evidence Act. This is a major challenge that was not covered by Section 84 of the Evidence Act.

Section 84(4) of the Evidence Act requires the production of a "certificate" identifying the document and or certifying the condition stated in subsection (2) of section 84 . This then brings about issues such as the way and manner the certificate will be issued, verification of the content of such document, the process of certification and more! In (Collins Commerce Nig. Ltd V. Skye Bank Plc), the contention was whether the document tendered complied with the mandatory provisions of Section 84 (4), The court in resolving the issue held, relying on Dickson v. Sylva and (Orogun \& Anor us. Fidelity Bank) aforementioned, that for electronically generated evidence to be admissible, it must comply with Section 84 (2) and must be certified as stated in subsection (4).

\subsection{Electronically Generated Information for Court Evidence and Proceedings}

Confessional Statement of offender: The probable way of reducing the possibility of trial within trial and allegation of torture in a confessional statement is the provision of an audio-visual recording system of obtaining system. In line with this, Section 15 (4) of the Administration of Criminal Justice Act (ACJA) provides that where a suspect volunteer to making a confessional statement, the statement be recorded electronically on a retrievable video compact disc. The ACJA however, does not make a strong step to achieve the much-desired effect above as the law itself has whittled down the said provision by providing that the inability to observe the said provision of section 15(4) does not make the said evidence inadmissible (S.15 (5) ACJA 2015; Igbinovia v. The State (1981) 2 SC 5).

Presentation of Evidence through Remote Hearing: Another area is the presentation of evidence through the application of remote hearing. It is notoriously known that evidence is the backbone of law. Evidence strives to establish the truth of every fact before the court via a series of process which involve the observation of the demeanour of witness, the veracity of the testimony of a witness also involve the ability of the witness to state his testimony without having to read a manuscripts except in cases of refreshing of memory as provided under the Evidence Act (S. 239 Evidence Act 2011). However, taking of evidence may not easily lend itself to virtual hearing in civil matters which constitutes the highest number of undecided and pending cases before the courts all over the nation, thus, slowing down the process of handling of cases in the courts nationwide. This is against the spirit and letters of the Preamble to the High Court of Lagos State Rule (No.1 "Expeditious Disposal of Civil Cases Practice Direction" 2019), which is in favour of speedy trial. 


\section{Time-Bound Cases and Urgency during the COVID-19 Period}

It has become pertinent to look at what constitutes time-bound cases or matters of real urgency, this has become so owing to the fact that the only cases that are envisaged not to be affected by the lockdown are those that are really urgent, time-bound and those that have to do with Fundamental Human Rights. Timebound cases are those that have a time-limit within which they can be pursued without which such case can be statute barred and of no legal effect once the time frame within which such case can be filed. On the other hand, cases of urgency refer to those cases that require prompt legal remedy without which an irreversible damage would be done to the subject-matter. For instance, Electoral cases are time-bound because they have to be decided within a specified period of time, that is, 180 days for the hearing and disposal of election petitions and 60 days for the disposal of any appeal arising there-from (S.285 (6) (7), CFRN, 1999).

This time stipulation is a rigid provision such that the Supreme Court has held in the case of (ANPP v. Goni (2012) that the specified period for deciding electoral cases is like Mount Zion or Mount Gibraltar which cannot be moved.

There is also a time limit under the statutes of limitation (Cap L84, Laws of Lagos State of Nigeria, 2015) for the period within which an action can be filed from the time that the wrong complained of occurs. In this peculiar circumstance, the inability of a litigant to access the Court to ventilate his claims would be due to the present supervening incapacity occasioned by the closure of the Courts, following the various Executive Orders of the Government (S. 1 (7) COVID-19 Regulations, 2020), made pursuant to Sections 2, 3 and 4 of the Quarantine Act, Cap Q2 LFN, 2004). This extraordinary occurrence however, is neither envisaged nor covered by the various Statutes of Limitation which are applicable in the various States across the country.

The Limitation Law of Lagos State (S. 8-12 of the Lagos state limitation law), for example, prohibits a party from seeking a remedy through a Court action, where such action is instituted after the expiration of the period prescribed by an enabling law for the institution of such action.(Osun State Government v Dalami Nig. Ltd. (2007). For instance, actions founded on simple contract must be brought within 6 years from the date on which the cause of action accrued; actions founded on instruments under seal must be instituted within 12 years from the date the cause of action accrued (S. 8-12 of the Lagos state limitation law). The rationale for the existence of a statute of limitation is that equity aids the vigilant, and not the indolent. Thus, a person who claims he has suffered a wrong, or who claims a right or remedy is required by a limitation statute to file an action in Court within the time prescribed and a failure to do so is fatal to such claim, as such action becomes statute-barred, and such person loses his right to institute an action in respect of such wrong or cause of action forever (Lagos state limitation law S.12). 
From the foregoing, it would be deduced that the pandemic situation has brought a rather unforeseen situation in the provisions operation of our law, the solution that has been proffered is that the period with which there was lockdown of court activities can be properly captured under the exclusion clause as stated in Paragraph 5 (c) of the Anambra state Practice Direction which provides that:

The period beginning from Monday, 23rd March, 2020 to Monday, 4th May, 2020 (six weeks), which was the period of the lockdown of the public service of Anambra State, is hereby declared. This period is excluded for the purpose of computation of time for doing any act under the Rules of Court.

Similar provisions exist in other jurisdictions. For example, the FCT Direction holds similar provision. It is also glaring that the provision above is nothing close to a solution to ameliorate the time-bar under the Limitation Laws. The provision above will only apply to computation of time under the High Court Civil Procedure Rules. Thus, the fate of litigants under the limitation law is still uncertain. It is suggested that situations such as pandemic circumstance although, not specifically contained as exceptions to limitation of time under the law; it should be imputed as one of the exceptions on the principle of lex non cogit ad impossibilia This legal maxim presupposes that, laws that pose themselves to be impossible to give effect to should not be allowed to thrive since law does not thrive on impossibilities.

\section{Constitutional Challenges of COVID-19 Induced Virtual Court Proceedings}

A hearing involves the taking of evidence, counsels are heard, arguments are taken and cases are determined within a judicial process. Such hearing must be public and unrestricted. The physical structure or space where the hearing is conducted ordinarily should not affect in any way the outcome of the proceeding. S.36 (1) of the Constitution of the Federal Republic of Nigeria (CFRN) 1999 (as amended in 2011) provides;

In the determination of his civil rights and obligations, including any question or determination by or against any government or authority, a person shall be entitled to a fair hearing within a reasonable time by a court or other tribunal established by law and constituted in such manner as to secure its independence and impartiality.

S. 36 (3) also provides that; "The proceedings of a court or the proceedings of any tribunal relating to the matters mentioned in subsection (1) of this section (including the announcement of the decisions of the court or tribunal) shall be held in public".

By these provisions, it is clear that the intent of the lawmakers is to ensure unrestrained access by litigants to court hearings and proceedings in public and 


\section{within a reasonable time.}

The questions arising from the various COVID-19-driven activities the virtual hearings and the directives thereof; could it be said that the virtual or remote hearing created by the new Practice Directions across the judiciary nationwide, in any way contravene the extant laws, especially the 1999 Constitution being the grundnorm of laws of the Federal Republic of Nigeria? What are the other challenges that are likely to hinder the smooth operation and the effective and efficient performance of the new technological framework for virtual or remote courts proceedings in Nigeria?

Although, the Attorney General of the Federation, and the National Judicial Commission are in full support of the Practice Directions issued by the CJN on May 4, 2020 (ref. No. NJC/CIR/HOC/II/660), this was done in order to support the operation of virtual court proceedings nationwide, to cushion the effects of COVID-19 on judiciaries. However, the legality of virtual court hearing or proceedings with its attended challenges is being challenged by some writers especially, by the legal practitioners.

Harold (2020) is of the view that the Nigerian Constitution and other substantive laws have no provisions to support virtual proceedings and practices. Section 36 (3) and (4) was quoted to support the illegality of virtual court hearings in Nigeria. To many authors like Harold, "any proceeding" held in this respect without amending the extant constitutional provisions and other substantive laws would amount to effort in futility. However, to other who are in support of remote hearings are of the views that, "the challenges posed by the effect of COVID-19 pandemic on the administration of justice, has called for the urgent need to leverage on technology in the efficient management of the justice sector and in particular, in the administration of justice and the courts" (Committee on "the Impact of COVID-19 on the Nigerian Justice Sector" May 2020).

Rapheal, is of the view that "every arm of the Government have been affected and impacted withCOVID-19 pandemic" (Rapheal, 2020), with no exception to courts being prevented from hearing cases; because judges were unable to sit safely, cases were also piling up without knowing when situation are likely to get better. Hence, there is need for new approach. However, while supporting the needs to adapt courts' proceedings to virtual hearing, he calls for caution that:

Without doubt, the COVID-19 pandemic has affected all areas of our society and no one can with any certainty, predict when it would end or how society will return to a new normal. Nonetheless, in piloting society to a new normal, all arms of the Government are charged to do their best to pilot the affairs of the society to a safe landing in the new normal land.

Rapheal (2020) stresses further that in this pandemic period, that court being the third arm of Government has enormous tasks to ensure that the rule of law "continues to operate" even in the face of the COVID-19 pandemic. In support of remote court hearings, Rapheal did rolls out some many advantages of courts virtual hearing; which include among others, the ensuring of online court pro- 
ceedings while the safety of the judges is guaranteed, so also the safety of litigants and their counsels, the prosecutors and their witnesses, as well as the protection of others courts' staff; speedy trial; "flexibility to accommodate several trials simultaneously"; cut down travelling expenses; processed data on all cases are generated online in real time; encouraging paperless court proceedings, and a host of other advantages recognises that these advantages are not without their own arrays of challenges, which include:

* Having to train and retrain the numerous judicial personnel to adapt to the new model;

* Problems associated with illiteracy of some of litigants and the witnesses who may not Be acquainted with the new mode of operation;

* Challenges of securing the cases going through zoom meeting software, Skype and other online gadgets without being scammed;

* Challenge of being subjected to too frequent changes and "reinventions in technology";

* Power shortage peculiar to developing world such as a nation like Nigeria;

* Office equipment to back up the effective and efficient operation of the new model.

In spite of these numerous challenges, Rapheal is very optimistic about virtual remote-hearing. He sees it as a global novel on course worth pursuing. Therefore, Nigeria as a nation should henceforth regard remote hearing as a "norm" rather than an "exception".

We are in absolute agreement with the above sounds of warnings (in spite of the obvious prospects or advantages of the remote hearing), for government to take precaution, especially, that in doing the needful, society would not disintegrate through the hands of those in position (the justice sector) to preserve the sanctity of laws in the society.

Cynthia C. Izu, (2020), while also supporting online devices to handle most of courts' practices and proceedings and several other areas of human endeavours; such as, health issues, corporate-commercial and all other contractual relationships in this Covid period and beyond; she notices that the commercial lawyers in the face of lock-down, can now prepare all documents of deeds and related issues at home and attach e-signature for onward transfer of those documents to clients without fear of getting infested with the deadly virus. She backs up her findings with some statutory provisions and cases that support e-transactions in legal practices in Nigeria; for instance, Section 17 of the Cybercrime (Prohibition and Prevention) Act, 2015; S. 84,93 (2) \& (3) Evidence Act 211 which make e-signature binding in the court of law in Nigeria. Several other cases are adduced to buttress her points that online legal practices, and e-transactions, e-governance, e-contracts, and the virtual court hearings have come to stay as a result of the COVID-19 pandemic outbreak (Metibaye v. Narelli Int'lltd (2009)). However, she entertains fear of the possibility of the rights of citizens-such as, right to data protection, right to privacy, rights to respect for human dignity while enforcing COVID-19 rules such wearing face mask, stay home-syndrome, 
and several other personal rights, which might be trampled upon in the course of enforcement and make-shifts to move on with life in every sector in the face of COVID-19. Hence, there is a call for caution.

In similar vein, Abimbola (2020) in her paper titled, "Human Rights Dimensions of COVID-19 Response", also express concerns for possible absence of maximum protection of rights of citizens in the face of a pandemic virus such as COVID-19. She noted the inalienability rights of human persons as guaranteed by international and national human rights provisions (International Covenant on Economic, Social and Cultural Rights (ICESCR), 1976; the Constitution of the Federal Republic of Nigeria, 1999); as well as limitation that may be imposed on those guaranteed rights, arising from national state of emergencies. She is of the view that, in as much as the government is obligated to take measures to prevent threats to public health in time of emergencies, any restrictions put in placed should be exercised in proportionate to human essential needs, respect for human dignity and personal liberty. We dare to say that, indeed, access to justice had been one of the greatest challenges arising from this COVID-19, as a result of the total short-down of Judiciary for more than two months in Nigeria; warranting the Practice Directions issued by the CJN on May 4, 2020 (ref. No. $\mathrm{NJC/CIR/HOC/II/660),} \mathrm{to} \mathrm{operate} \mathrm{virtual} \mathrm{courts} \mathrm{proceedings,} \mathrm{which} \mathrm{was} \mathrm{subse-}$ quently adopted by various High Courts across the nation, to ameliorate the pandemic situation orchestrated by COVID-19. However, the need to take due caution in operation of the new model so as not to jeopardise the entire processes of justice delivery system cannot be overemphasized

From the foregoing, one cannot, but be in agreement to support the various views expressed by the various Authors (Sheeran, 2013), as regards the prospects and challenges of the new mode of operating the judiciary sector. We are of the view that although, virtual hearing is a child of necessity brought about by the exigency of COVID-19; however, government must tread with cautions to check and balance, in order to have smooth, efficient and effective operation of the new trend of online devices or technological framework for handling justice sector. Fortunately, the provisions of the National Judicial Policy of 2018 which came into operation in 2019 even before the outbreak of COVID-19, and the subsequent Practice Directions across courts in the nation, appears to be in full support of digitalisation of courts proceedings and practices across the judiciary sector in Nigeria. It provides as follow:

As a matter of policy, the National Judicial Council stipulates that:

(a) The Judiciary in Nigeria both at the Federal and the State levels shall encourage the use of Information and Communication Technology (ICT) and, in particular, all courts shall, as far as practicable, predicate and integrate their Information Technology System on the Judicial Information Technology Policy of the Federal Republic of Nigeria when adopted.

(b) Judicial Bodies and Institutions shall be equipped with Information Technology Systems. 
(c) All Judicial Officers shall undertake mandatory training on use and application of Information Technology Systems including electronic and digital recording and transcription of court proceedings and processes. No.2.4.10 (a), (b) and (c), National Judicial Council 2018).

In consonance with these provisions, it has been argued back and forth that the present provisions of Practice Directions which include holding virtual or remote proceedings in order to cushion the effect of Lock down in the justice sector is in order. Similarly, noting the recent decision of the High Court of the Federal Capital Territory Abuja, in conducting a virtual mock trial proceeding in Ogunwunmiju SAN v. Okutepa SAN (Suit No. FCT/HC/CV/001/2020). Justice Peter Affen held that Clause 9 of the FCT High Court COVID-19 Practice Direction which provides for remote hearing is neither unconstitutional nor offends section 266 of the Administration Criminal Justice Act (ACJA 2015); which provides to the effect that;

"A defendant shall, subject to the provisions of section 135 of the Act, be present in court during the whole of his trial" unless:

1) He misconducts himself in such a manner as to render his continuing presence impracticable or undesirable; or

2) At the hearing of interlocutory application.

It is our view that although, at the promulgation of the Constitution, it was not envisaged that a pandemic situation such as created by the deadly virus would arise to warrant creating an exceptional proviso for the safe landing of Practice Directions that would enable court proceedings by virtual sittings. However, there is enough room in the Constitution of our nation to accommodate cases of emergency. In fact, S. 273 of the Constitution appears to support the new Practice Direction in the prevalent circumstances of CCOVID-19. It provides thus, "For the purpose of exercising any jurisdiction conferred upon it under this Constitution or any law, a High court of a State shall be duly constituted if it consists of at least one Judge of that Court".

Even though, the matter pertaining to the legality of remote hearing in court proceedings in Nigeria remains unsettled, it is our strong view and contention that a State High Court in Nigeria is properly constituted if at least one judge properly admitted and sworn in to hear and determine matters sits in an unrestricted public hearing such as occasioned by the pandemic virus, in so far such remote hearing does not bring about miscarriage of justice. Hence, the emphasis is on the constitution of the Court and not the physical structure or space. This may seem to be the reason why in-camera hearings held in judge's chambers retain the validity of a hearing.

In a virtual hearing, counsels and litigants present their evidence before a judge in a virtual space that is unrestricted and public. Where cases are conducted in this manner, it is submitted that such qualifies as a valid public hearing within the purview of the law. In Nigeria and indeed in many countries of the world such as the United States of America, this grey area is being exploited 
and has been used to dispense of civil and criminal matters at all levels of court.

\section{Summary}

Although COVID-19 has posed serious economic, social and legal threats to the world, valuable gains have been made in discovering newer opportunities to counter the challenges of the disease through technology. This is more evident in the area of virtual hearings and the more frequent use of electronic evidence, particularly employed to ensure judicial expediency. There is no doubt that the lock-down of all courts, social and public infrastructures and indeed persons occasioned by COVID-19 has impacted justice delivery greatly.

Access to courts for the enforcement of rights has been a major concern for many human rights advocates. Proactive measures employed by the heads of court and the government of Nigeria both at the federal and state levels have worked to assuage the serious clogs in the judicial wheel of progress.

The pandemic therefore provided a unique opportunity to the judicial arm and the legal community as a whole to pursue vigorously, within the dilemma of rights, a moral and legal elixir of rights and judicial expediency.

\section{Conclusion}

COVID-19 has created a novel situation where inventive and necessary ideas are developed to cope with the new normal, daily work, new social interactions and institutional changes that must be sustained to maintain the health and safety of the general populace. Technology has stepped in to keep people together socially but commercial transactions and business initiatives need a bit more to adequately provide for significant security and economic sustainability that is so much required. The appeals that will follow the recent cases being determined by electronic and technological means will be pointers to specific areas of the law asides from those mentioned in this paper. For example, S. 295 of the Constitution of the Federal Republic of Nigeria (1999 as amended in 2011) talks about reference of a constitutional matter to higher courts of record. The court shall refer such to the court of higher hierarchy upon the application for such by any party. This and many other provisions of laws and Practice Directions, although, might be compromised in "period of exigency" such as the present COVID-19 pandemic situation; but by no means shall those provisions in any way be undermined in the course of moving in the face of COVID-19 in Nigeria.

The necessary elixir between speedy judicial processes must be balanced such that the rights of the people are not jeopardised in any way. The role of technology is key and cannot be separated or discountenanced as a lawyer. It is the anchor to the development of the law in Nigeria and indeed the world.

\section{Conflicts of Interest}

The authors declare no conflicts of interest regarding the publication of this paper. 


\section{References}

Abimbola, H. (2020). Human Rights of Dimensions of COVID-19 Response. Loyal Nigerian Lawyer Publication.

Harold, B. (2020). Covid-19: The Legality of Virtual Court Proceeding in Nigeria. The Nigerian Lawyer Online News. Thenigerianlawyer.com.

Izu, C. C. (2020). Emerging Issues and Practicable Legal Approach in the Face of Covid-19: A Demand to Expand the Technological Framework in Nigeria. Loyal Nigerian Lawyer Publication.

Nigerian Institute of Advanced Legal Studies (NIALS) (2020). Report of the Committee on "the Impact of Covid-19 on the Nigerian Justice Sector".

Rapheal, C. (2020). Covid-19: Challenges for Courts and Court Users. Loyal Nigerian Lawyer Publication.

https://loyalnigerianlawyer.com/covid-19-challenges-for-courts-and-court-users

Sheeran, S. P. (2013). Reconceptualising States of Emergency under International Human Rights Law: Theory, Legal Doctrine, and Politics. Michigan Journal of International Law, 34, 491.

Stanley-Idum, M. M., \& Agaba, J. A. (2015). Civil Litigation in Nigeria (p. 267). Lagos: Nelag Co. Ltd.

\section{Statutes}

Administration of Criminal Justice Act, 2015.

Anambra State High Court COVID-19 Practice Direction, 2020.

Constitution of the Federal Republic of Nigeria 1999 (as Amended in 2011).

COVID 19 Practice Direction for Remote Hearing of Cases in the FCT, 2020.

COVID 19 Practice Direction for Remote Hearing of Cases in the Lagos State Judiciary, 2020.

COVID-19 Practice Direction of the High Court of the Federal Capital Territory, 2020.

Evidence Act, No. 18, 2011.

High Court of Lagos State Expeditious Disposal of Civil Cases Practice Direction, No. 1 of 2019.

Hon. Justice O. M. Anyachebelu, Practice Direction No. 2, 2020 Anambra.

Lagos State Limitation Law Cap L84, Laws of Lagos State of Nigeria, 2015.

National Judicial Council Policy No.2.4.10 (a), (b) and (c), 2018.

Paragraph 7 Practice Directions for Remote Hearing of Cases in the Lagos State Judiciary, 2020.

Paragraph 9 of the Practice Direction of the FCT, 2020.

Quarantine Act, Cap Q2 LFN, 2004.

Section 15 (5), Administration of Criminal Justice Act (ACJA), 2015.

Section 210 Criminal Procedure Act.

Section 239, Evidence Act, 2011.

Section 266, Administration of Criminal Justice Act (ACJA), 2015.

Section 285 (6) (7), Constitution of the Federal Republic of Nigeria, 1999.

Section 295 of the Constitution of the Federal Republic of Nigeria 1999 (as Amended in 2011). 
Section 36 of the Constitution of the Federal Republic of Nigeria, 1999.

Section 86, 88 and 92 of Administration of Criminal Justice Law of Lagos (ACJL 2017).

\section{Cases}

Adams v. Lindsell (1818) 1 B \& A 681.

ANPP v. Goni (2012) JELR 57199 (SC).

Buhari v. INEC (2008) 19 NWLR (Pt. 1120) 236 at 341-342.

Chief of Air Staff v. Iyen (2005) ALL FWLR (pt. 252) p. 425.

Collins Commerce Nig. Ltd V. Skye Bank Plc.

Dickson v. Sylva (2017) 8 NWLR, PT1567, 167.

Ezeze v. The State (2005) ALL FWLR (Pt. 255), p. 119.

GaniatAmope Dilly v. Inspector General of Police (2016) LPELR 41452 (CA).

Igbinovia v. The State (1981) 2 SC 5.

Olubunmi Okogie v. Attorney-General of Lagos State (1981) 1 N.C.L.R 218.

Orogun \& Anor v. Fidelity Bank (2018) LPELR-46601.

Osun State Government v. Dalami Nig. Ltd (2007) 9NWLR (Pt 1038).

RansomeKuti v. Attorney-General of the Federation (1985) 8 NWLR (Pt. 6) 211.

Shuaibu v. Muazu (2007) 7 NWLR (Pt. 1033) 271.

State of Lagos v. Olalekan Hameed (2019) Unreported, Charge No.ID/9006C/2019 delivered 4th May, 2020.

Metibaye v. Narelli Int'll Ltd. (2009) 19 NWLR (Pt. 1120) 236 at 341-342.

Nwakwo v. Yar’adua (2010) 12 NWLR (Pt. 1209) 518. 